\title{
METAMORPHISM IN THE FISKENÆSSET REGION
}

\section{Feiko Kalsbeek}

\section{Introduction}

This study is based on a collection of 300 rock samples, taken on the basis of a grid consisting of equilateral triangular cells within a region of $c .4000 \mathrm{~km}^{2}$ between Grædefjord and Frederikshåbs Isblink. The localities were visited by helicopter, two samples being taken at each of 150 grid points. To promote unbiased sampling, location of the grid points in the field was left to the pilot. It was attempted to obtain two representative samples at each locality, but due to the inhomogeneity of the rocks the choice of representative samples was generally a matter of personal judgement. The collection can therefore at best be regarded as representative for the region, but not as a random sample. No samples of the late dolerite dykes of the area were taken, with one exception, even if the sample point (landing place) was on one of these dykes.

Thin sections of the 300 samples were studied. The volumetric percentages of the main minerals were visually estimated and the presence of accessory minerals was noted. In addition, the anorthite content of the plagioclase in a number of samples was measured, the colour of the hornblende was noted and the degree of alteration of the samples was assessed.

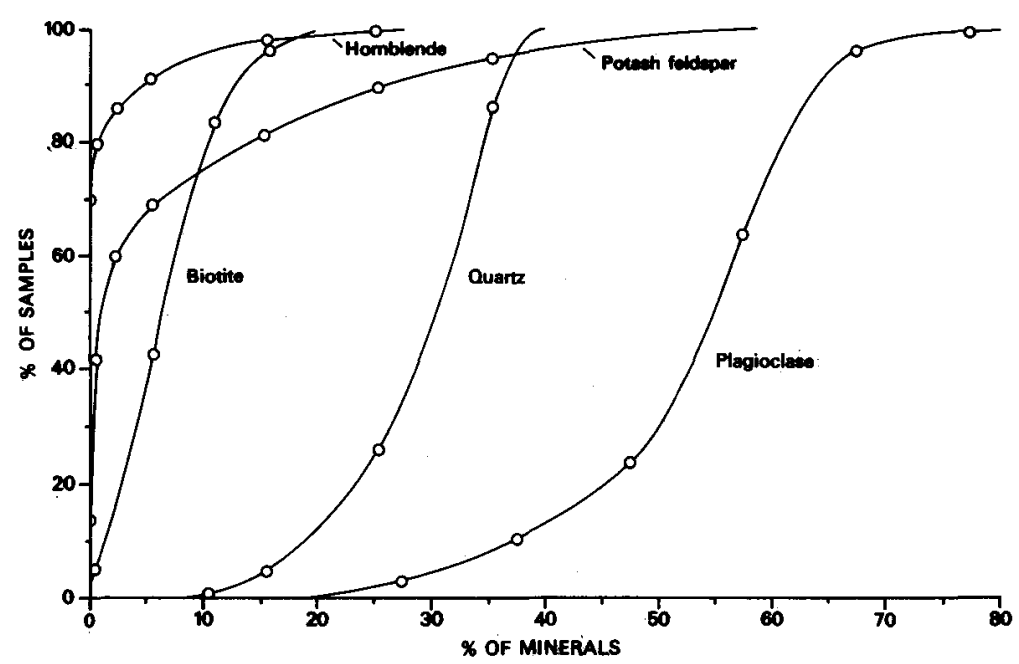

Fig. 17. Composition of the gneisses. The diagram shows the percentage of samples having less than the amounts of the different minerals shown. 
Table 3. Distribution of major rock types in the Fiskenasset region

\begin{tabular}{|c|c|c|}
\hline & & volume $\%$ \\
\hline Gneisses & & $84 \cdot 3$ \\
\hline Granitic gneiss (K-feldspar $>20 \%)$ & 16.0 & \\
\hline$K$-feldspar gneiss $(10 \%<K-f d s p<20 \%)$ & 9.0 & \\
\hline Plagioclase gneiss $(K-f d s p<10 \%, h b l .<10 \%)$ & 52.0 & \\
\hline Hornblende gneiss (hornblende $>10 \%$ ) & 5.3 & \\
\hline \multirow[t]{2}{*}{ Quartz-poor gneiss (quartz $<10 \%$ ) } & 2.0 & \\
\hline & 84.3 & \\
\hline Amphibolites & & $9 \cdot 3$ \\
\hline Anorthositic and associated rocks & & 5.0 \\
\hline other rocks (mylonite, albitite, dolerite) & & 1.3 \\
\hline & & 99.9 \\
\hline
\end{tabular}

\section{Distribution of rock types and general composition of the gneisses}

The distribution of the major rock types: gneisses, amphibolites and anorthositic rocks (Table 3) agrees well with earlier estimates based on sand samples (Kalsbeek et al., 1974). The most common gneiss type has a tonalitic to granodioritic composition (Table 3), generally with less than $10 \%$ microcline. More granitic gneisses also occur and microclinerich gneisses ( $>20 \%$ microcline) seem to be more common than gneisses with $10-20 \%$ microcline. A few samples of quartz-poor gneisses with dioritic to syenitic compositions were also found.

Biotite is the most common mafic mineral in the gneisses averaging $8 \%$, while hornblende occurs in about a third of the samples (fig. 17). Microcline and hornblende generally do not occur together in the same sample. Of the 253 gneiss samples, 149 contain more than traces of microcline, 51 contain more than traces of hornblende, and only 12 contain both minerals and then generally in small amounts $(<5 \%)$. Hypersthene and diopside occur in a number of gneiss samples in the north-western part of the region whereas muscovite and epidote are found as late porphyroblasts in many gneiss samples from the southern (low grade) part of the terrain. Garnet occurs in six of the gneiss samples, and sillimanite has been found in only one sample. Other metamorphic indicator minerals such as kyanite, cordierite and staurolite have been found in the area but do not occur in the grid collection. Allanite, apatite, opaque minerals, sphene and zircon are common accessories in the gneisses. The opaque minerals are more abundant in the north-western (high grade) part of the region, and sphene is more common in the southern (lower grade) part. 


\section{Metamorphic zoning}

On the basis of the 300 samples from the grid collection it was attempted to define zones of different metamorphic grade. Due to the scarcity of suitable rock compositions to provide index minerals, this proved to be difficult, but some preliminary results were obtained. The information that has been used is listed below:

Hypersthene is restricted to the north-western part of the region and a minor area just north-west of the head of Bjørnesund. It occurs both in gneisses and in amphibolites.

Diopside occurs irregularly in a large area in the northern part of the region; it is found in amphibolites, anorthositic rocks and in some of the gneisses. In the southern, lower grade, part of the terrain, diopside has only been found in one amphibolite very near to Frederikshåbs Isblink. It is possible that the metamorphic grade increases again further south-east. Abundant hypersthene hàs been found in sands collected at the front of Frederikshåbs Isblink (Kalsbeek et al., op. cit.), and Dawes (1970) has found hypersthene in metamorphosed basic dykes on Dalagers Nunatakker.

Hornblende varies in colour from brownish green in the north-western higher grade terrain to distinctly bluish green in the southern lower grade terrain. In a number of cases brownish green hornblende occurs as cores in bluish green hornblende, indicating a decreasing grade of metamorphism. Although these colour descriptions are subjective, they are confirmed by repeated observations. Brownish green hornblende surrounded by bluish green hornblende has also been found near Frederikshåbs Isblink.

Epidote occurs especially in the gneisses in the southern part of the region. Epidote occurs both as a clearly secondary mineral in altered rocks (generally replacing biotite and often inheriting trains of inclusions parallel with the cleavage of the original biotite crystals) and as porphyroblasts (often poikiloblasts) without a secondary appearance. The latter may occur in completely fresh rocks in which the plagioclase $\left(\mathrm{An}_{25-30}\right)$ does not visibly change composition towards bordering epidote crystals. In these fresh rocks the epidote is also often associated with the biotite, and the impression is gained that these rocks may have formed by progressive metamorphism of altered gneisses. Epidote does not normally occur in the amphibolites; where it occurs it is clearly secondary.

Muscovite occurs in the same general area as the epidote, but unlike the epidote it is restricted to gneisses without hornblende. Muscovite also occurs both in strongly altered rocks as a clearly secondary mineral, and in fresh rocks as porphyroblasts (poikiloblasts) up to $c .1 \mathrm{~mm}$ in length. Both the muscovite and the epidote porphyroblasts commonly show myrmekitic rims.

It was hoped that the distribution of these minerals plotted on the map (fig. 18) would define a regular metamorphic zoning. This is hardly the case. Hypersthene-bearing rocks (hornblende granulite facies) occupy a sickle-shaped area in the north-western part of the region with one arm running southwards along the coast and one arm passing the inner part of Fiskenæsfjorden. An outlier of hypersthene-bearing rocks, seemingly in line with this eastern arm, occurs north of the inner part of Bjørnesund. Rocks with diopside and (brown-)green hornblende but without hypersthene (high rank amphibolite facies) occur scattered throughout the area north of Bjørnesund. These rocks do not define a regular zone around the areas of hornblende granulite facies rocks. Rocks with epidote and muscovite porphyroblasts and with bluish green hornblende (low rank amphibolite facies), define a coherent area in the southern part of the region. Small epidote and muscovite porphyroblasts $(<0.5 \mathrm{~mm})$, and bluish green hornblende, occur scattered throughout the rest of the region, but rarely in hypersthene-bearing rocks. The distribution of the accessory opaque minerals and sphene is clearly related to the distribution of the main minerals, sphene occurring especially in the lower grade part of the region and opaque minerals in the higher grade part. 


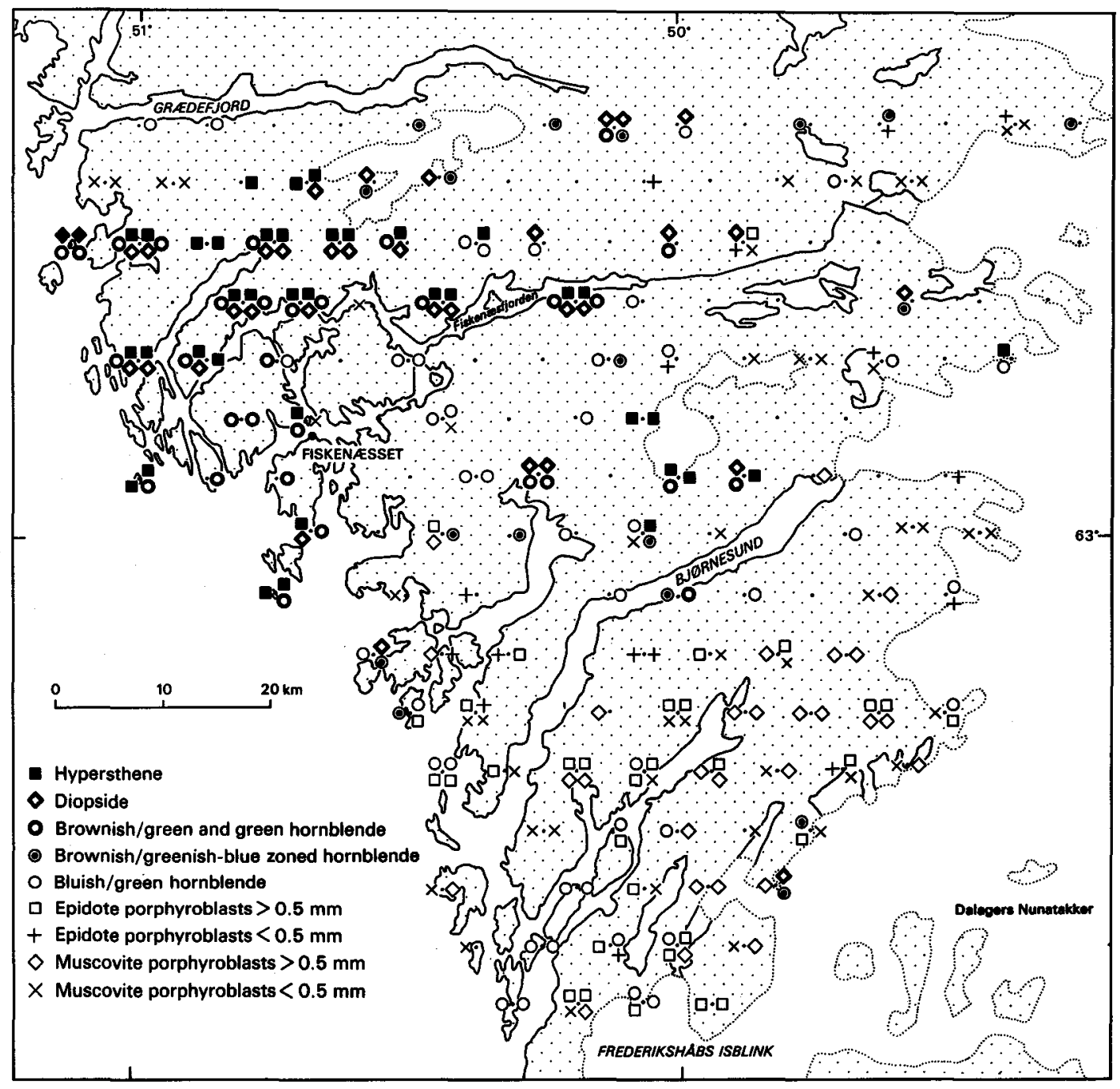

Fig. 18. Distribution of some metamorphic minerals in the Fiskenæsset region.

\section{Composition of the plagioclase}

There is no clear relationship between the anorthite content of the plagioclase and the grade of metamorphism of the rocks (Table 4). In the Alps the composition of the plagioclase in amphibolites has successfully been used to define isogrades (Wenk \& Keller, 1969), but in the Fiskenæsset region no simple relationship has been found. Some of the hypersthene and diopside-bearing amphibolites have plagioclase as sodic as $A_{30}$ and plagioclase from some of the amphibolites with bluish green hornblende may be as calcic as An70. Andersen (1974) found very calcic plagioclase (up to Anso) together with bluish green hornblende in amphibolites of the Ravns Storø belt in the southern part of the 
Table 4. Composition of the plagioclase

\begin{tabular}{|c|c|c|c|c|}
\hline Rock type & $\begin{array}{l}\text { Lowest } \\
\text { An value }\end{array}$ & $\begin{array}{l}\text { Most common } \\
\text { An value(s) }\end{array}$ & $\begin{array}{l}\text { Highest } \\
\text { An value }\end{array}$ & $\begin{array}{c}\text { Number of } \\
\text { determinations }\end{array}$ \\
\hline \multicolumn{5}{|l|}{ Hypers thene } \\
\hline amphibolites & 26 & $30-38$ & $>60$ & $(38)$ \\
\hline \multicolumn{5}{|l|}{ other } \\
\hline amphibolites & 24 & $35-45$ & $>60$ & (83) \\
\hline \multicolumn{5}{|l|}{ Hypers thene } \\
\hline gneisses & 22 & 27 & 37 & $(128)$ \\
\hline \multicolumn{5}{|l|}{ Epidote and } \\
\hline muscovite gneisses & 21 & 27 & 31 & $(82)$ \\
\hline Hornblende gneisses & 22 & 27 & 37 & $(53)$ \\
\hline Granitic gneisses & 20 & 22 & 27 & $(40)$ \\
\hline Other gneisses & 22 & $23,25,27$ & 30 & $(60)$ \\
\hline
\end{tabular}

Fiskenæsset region. This and other evidence led Andersen to the conclusion that these rocks had undergone low pressure contact metamorphism (hornblende homfels facies) during the intrusion of the surrounding tonalites. The plagioclase in these often fine grained amphibolites is generally untwinned and strongly zoned, whereas the plagioclase in the other amphibolites (also from the southern part of the region) is well-twinned, hardly zoned and generally more sodic. Plagioclase in equilibrium with calcite in siliceous marble and calc-silicate rock from the southern part of the region is also fairly sodic $\left(\mathrm{An}_{25-30}\right)$.

\section{Alteration of the rocks}

A number of rock samples proved to be down-graded to greenschist facies parageneses to a variable degree. In these rocks the plagioclase is altered to albite and sericite and the biotite to chlorite and epidote. Hornblende is generally much less altered than biotite, and K-feldspar much less so than plagioclase. K-feldspar rich rocks are generally more strongly altered than K-feldspar poor rocks.

To assess the degree of alteration each rock was assigned a numerical value between 0 (completely fresh rock) to 8 (completely altered rock), this number being the sum of alteration numbers $0-4$ for respectively the felsic minerals and the mafic minerals (0: very fresh, 2: moderately altered, 4: completely altered). Estimation of an alteration index in this way proved to be repeatable. Plotting on the map (fig. 19) shows that strongly altered rocks occur especially in the north-eastern and southern parts of the region.

In the north-eastern part of the region indications of high rank amphibolite facies metamorphism and in one case granulite facies metamorphism are still found, but in the 


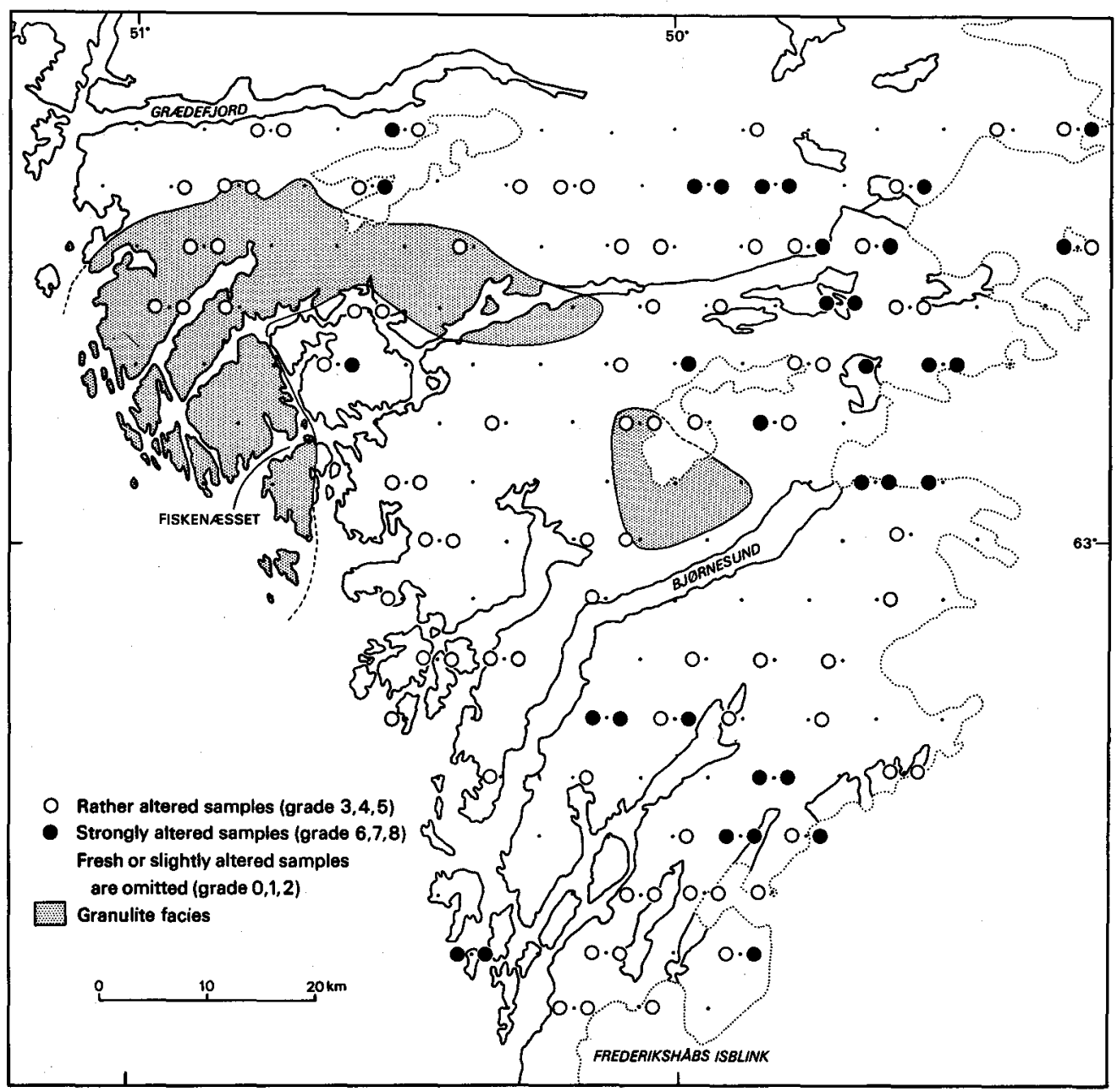

Fig. 19. Distribution of altered rocks in the Fiskenæsset region. For the different grades of alteration see the text. The delimitation of the granulite facies terrain is simplified.

southern part of the terrain almost exclusively low rank amphibolite facies rocks (epidote, muscovite) occur. There is some evidence to indicate that the fresh epidote-bearing rocks developed by prograde metamorphism of earlier down-graded (greenschist facies) rocks: (1) The general agreement between the occurrence of fresh epidote-bearing rocks with that of strongly altered rocks.

(2) The fact that in the strongly altered rocks only rarely is 'fresh' epidote found, but much turbid, clearly secondary epidote occurs. This is also the case in the southern part of the region where most fresh gneisses contain large epidote porphyroblasts.

(3) In a number of strongly altered rocks secondary biotite is found replacing chlorite (fig. 20), and indicates an increase of temperature following the low grade alteration. 


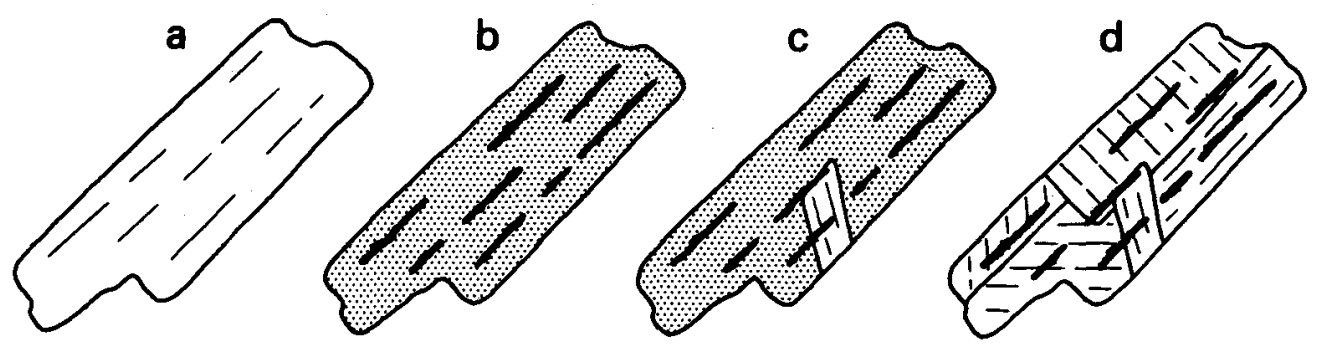

Fig. 20. Sketch of different stages of recrystallisation of biotite. a: fresh biotite; b: totally chloritised biotite with trains of fine grained sphene; $c$ : same with small new-formed biotite crystal; d: totally recrystallised biotite.

\section{Discussion}

The rocks in the region are mainly representative of three metamorphic grades: (1) hornblende granulite facies (especially in the north-western part of the region); (2) high rank amphibolite facies (scattered throughout the northern part of the region); and (3) low rank amphibolite facies (especially in the southern part of the region). Rocks belonging to all three grades may be completely fresh and apparently consist of stable parageneses. The metamorphic zoning does not show a clear relationship with the large scale structures and the final phases of metamorphism may be post-deformation. Throughout the region the rocks are migmatitic, and since field and experimental evidence (Winkler, 1967) shows that the formation of migmatites requires at least high rank amphibolite facies temperatures, the rocks in the southern part of the region must have been of higher grade originally. In the thin sections, however, no evidence of earlier higher grade parageneses has been found. It is possible that the rocks underwent a phase of greenschist facies alteration before the occurrence of the low-rank amphibolite facies metamorphism.

There is very little indication of the pressures at which the metamorphism took place. Cordierite and kyanite have both been found locally, but are so rare that as yet nothing can be said about the distribution of these minerals. Theoretically, steep thermal gradients would be expected in these Archaean rocks (Fyfe, 1973), but field and thin section evidence tends to give a different impression. Throughout the Archaean gneiss block migmatites are predominant indicating a rather narrow range of temperatures during metamorphism. Greenschist facies rocks are very rare and homogeneous granitoid rocks are uncommon, indicating that temperatures were too low for large scale melting of the rocks. Granulite facies rocks, although not rare, may be absent over large areas. Although not absolutely incompatible with steep thermal gradients, these small variations of metamorphic temperatures over so large a region would be in better agreement with shallower gradients. This might then indicate that the Archaean crust was already fairly thick at the time of the final metamorphism, a possibility that cannot be excluded in view of the very low content of radioactive elements in these rocks (Kalsbeek, 1974). 


\section{References}

Andersen, L. S. 1974: Rapport over geologien mellem Frederikshåbs Isblink og Quvnilik fjord - Vest Grønland. GGU internal report.

Dawes, P. R. 1970: Bedrock geology of the nunataks and semi-nunataks in the Frederikshåbs Isblink area of southern West Greenland. Rapp. Grønlands geol. Unders. 29, 60 pp.

Fyfe, W. S. 1973: The generation of batholiths. In P. J. Wyllie (edit.) Experimental petrology and global tectonics. Tectonophysics 17, 273-283.

Kalsbeek, F. 1974: U, Th and K contents and metamorphism of Archaean rocks from South-West Greenland. Bull. geol. Soc. Denm. 23, 124-129.

Kalsbeek, F., Ghisler, M. \& Thomsen, B. 1974: Sand analysis as a method of estimating bedrock compositions in Greenland, illustrated by fluvial sands from the Fiskenæsset region. Bull. Grønlands geol. Unders. 111, $32 \mathrm{pp}$.

Wenk, E. \& Keller, F. 1969: Isograde in Amphibolitserien der Zentralalpen. Schweiz. Miner. Petr. Mitt. 49, 157-198.

Winkler, H. G. F. 1967: Petrogenesis of metamorphic rocks. (2nd edit.). Berlin: Springer. 